\title{
Comparison of Different Types of Fertilizers on Growth, Yield and Quality Properties of Watermelon (Citrllus lanatus)
}

\author{
Mohammed Massri', Louay Labban² \\ ${ }^{1}$ Department of Food Sciences, Faculty of Agriculture, Al-Baath University, Homs, Syria \\ ${ }^{2}$ Department of Nutrition and Food Sciences, Faculty of Health Science, University of Kalamoon, \\ Dier Attiah, Syria \\ Email: drlouay@gmail.com
}

Received 16 February 2014; revised 5 April 2014; accepted 22 April 2014

Copyright (C) 2014 by authors and Scientific Research Publishing Inc.

This work is licensed under the Creative Commons Attribution International License (CC BY). http://creativecommons.org/licenses/by/4.0/

(c) (i) Open Access

\begin{abstract}
Background: Watermelon is a very important crop because it has many nutritional and economical values. This crop is known to human for ages and has been cultivated for centuries in many Middle Eastern countries including Syria. Several types of fertilizers are being used in order to increase the productivity of this crop but some fertilizers have shown to have an adverse effect on environment. Therefore, the aim of this study was to examine the effects of several types of organic fertilizers (cow, sheep, poultry and pigeon manure) and to compare their effects on growth, productivity and quality parameters with chemical fertilizers (NPK) and control group. Materials and Methods: Two local cultivars spherical and cylindrical (Audrey and Shapah) were used to examine the effects of cow manure ( $8 \mathrm{~m} /$ Donum), Sheep manure $(6 \mathrm{~m} /$ Donum), poultry manure $(3$ $\mathrm{m} /$ Donum) and pigeons ( $2 \mathrm{~m} /$ Donum) and were compared with chemical fertilizer ( $\mathrm{N} \mathrm{20:P} \mathrm{40:K}$ 25). Number of fruits on each vine, length of each vine (cm), fruit weight (kg), and estimated yield (kg/Donum) were measured and recorded some quality parameters such as rind thickness (cm) and heart color as well. Results: Cows manure was proved to be superior to other types of fertilizers (organic and inorganic) in many traits but chemical fertilizer gave the highest yield (kg/Donum) in Audrey cultivar but in Shapah cultivar there was no significant difference in productivity between chemical fertilizer compared with control group. Conclusion: Using organic fertilizers to cultivate watermelon does affect quality of watermelon and the productivity was closely related to chemical fertilizer. On the other hand, organic fertilizer can reduce the harmful effects of chemical fertilizers on environment and human health alike.
\end{abstract}

\section{Keywords}

Audrey, Shapah, Manure Fertilizers, Chemical Fertilizers, Productivity, Watermelon

How to cite this paper: Massri, M. and Labban, L. (2014) Comparison of Different Types of Fertilizers on Growth, Yield and Quality Properties of Watermelon (Citrllus lanatus). Agricultural Sciences, 5, 475-482.

http://dx.doi.org/10.4236/as.2014.56048 


\section{Introduction}

Human have known watermelon (Citrullus lanatus) for centuries and noticed the nutritional importance of its fruits. Watermelon is a herbaceous creeping plant belonging to the botanical family curcurbitaceous or gourd family which thrive in the tropical region and has been cultivated for thousands of years in the Middle East (Syria, Egypt, Jordan, Tunisia, Lebanon, etc.) and South East Asia [1]. Watermelon is very rich in source of nutrients such as photochemical and lycopene [2] [3] and often used as an appetizer or healthy snack, depending on the way it is prepared [4].

There are many local names for watermelon in the Middle East regions such as Bateekh in Syria, Habhab in Saudi Arabia, Raki in Iraq, Jah in UAE. Watermelon is considered as a summer crop and it has good economical importance because it is highly marketed crop in the local markets and for export. Watermelon is among the most widely cultivated crops in the world and the acreage of watermelon increased in the past years [5]. According to FAO 2011, Syria produces 670,559 tons and the cultivated area was 31,044 hectares [6].

Watermelon not only tolerates hot weather but for best growth requires more heat than any other vegetables. Watermelon seeds germinate well and plants thrive at $25^{\circ} \mathrm{C}-30^{\circ} \mathrm{C}$. Fruits mature best at $30^{\circ} \mathrm{C}$. Watermelon $\mathrm{Ci}$ trullius lanatus plant is a herbaceous creeping plant which produces from 3 to 5 fruits weighing from 3 to $10 \mathrm{ki}-$ lograms, some cultivars such as the "Florida Giant" may weigh up to 20 kilograms [7].

In order to improve the yield of watermelon, the soil content of nutrients should be increased to increase the fertility which can be achieved by either using organic fertilizer such as cattle manure, poultry manure, animal waste and use of compost [8] or by using chemical fertilizers mainly Potassium and Nitrogen compounds.

Scientists have been interested in studying organic materials especially for its benefits for the plant, soil and recently for the environment. Modern farming system is heavily dependent on chemical fertilizers and reducing the number of farmers who use organic fertilizers which created a wide range of problems mainly depleting the soil fertility and thus reducing the yield year after year, putting some farmers out of business not to mention that the effects on the soil texture since organic fertilizers can improve the soil texture especially the clay and sandy soils [9].

Over-use of chemical fertilizer can be harmful to environment by polluting water and increasing the volumes of farm crops proved to be hazardous to human health. In organic farming, the soil becomes rich in nutrients, therefore, crops grow healthy and can be resistant to pests and diseases, making the quality of the products more nutritious, tastier and contain substances that are good for health [10].

John et al., 2004 had advocated for an integral use of organic manure and inorganic fertilizers for the supply of adequate quantities of nutrients to improve crop productivity while minimizing environmental impact from fertilizer use [11].

Large quantities of animal wastes are produced each year in Syria, and mismanagement of organic wastes, have impacted public health and environment.

The aim of the study was to assess the effects of different types of organic fertilizers (cow manure, sheep manure, poultry manure and pigeon manure) and one type of chemical fertilizer (NPK) on the characteristics of watermelon (growth parameters, yield and quality) of two local cultivars in Syria.

\section{Materials \& Methods}

Four different types of fermented (for one year) organic fertilizers (cows, sheep, poultry, and pigeons) were used in addition to one chemical fertilizer as shown in Table 1.

Table 1. Type of fertilizers and the amount used in the experiment.

\begin{tabular}{cc}
\hline Treatment & Type of organic fertilizer(amount used) \\
\hline 1 & Cow manure $\left(8 \mathrm{~m}^{3} / \text { Donum }\right)^{*}$ \\
2 & Sheep manure $\left(6 \mathrm{~m}^{3} /\right.$ Donum $)$ \\
3 & Poultry manure $\left(3 \mathrm{~m}^{3} /\right.$ Donum) \\
4 & Pigeon manure $\left(2 \mathrm{~m}^{3} /\right.$ Donum) \\
5 & Chemical fertilizer (NPK) $20-40-25 \mathrm{~kg} /$ Donum \\
6 & Control (no fertilizers) \\
\hline
\end{tabular}

${ }^{*} 1$ Donum $=1000$ Square meters. 
The fertilizer is added to the soil prior to cultivation, and then seedlings are brought from nursery and planted in the soil after irrigation at a distance of 1.5 meter of each other.

Two local cultivars were used: Audrey round (spherical shape) and Shapah oblong (cylindrical shape). The experiment was replicated in three times and the average was calculated.

Physical properties of watermelon: the physical properties were determined for each cultivar including width and length circumference of the fruits $(\mathrm{cm})$, thickness of the rind $(\mathrm{cm})$ and weight of the fruits $(\mathrm{kg})$, percentage of the seeds, vine length and number of the branches in each plant were measured.

Estimated productivity was calculated by multiplying the number of fruits in each plant by the average fruit weight. Three fruits were left to grow in each plant.

\section{Methods of Analysis}

The following measurements were taken after 25 days of transplantation:

The number of branches in each plant, the length of each vine $(\mathrm{cm})$, the number of fruits in each vine, the weight of fruit (kg), estimated yield (kg/Donum) and the rind thickness $(\mathrm{cm})$ were taken 75 days after plantation.

1. Moisture determination was determined by drying the flesh in an oven at $105^{\circ} \mathrm{C}$ until a constant weight according to [12].

2. Ash content determination was determined in muffle at $525^{\circ} \mathrm{C}$ according to the [12].

3. $\mathrm{pH}$ measurement: By using Jenway $\mathrm{pH}$ meter 3510 according to [12].

4. Texture measurement: A Stable Micro System TA.XT computerized digital texture analyzer equipped with $(\mathrm{P} / 10)$ cylindrical probe and Cell $(5 \mathrm{Kg})$ and speed $2.0 \mathrm{~mm} / \mathrm{sec}$ to depth $10 \mathrm{~mm}$, were used. It was measured for the heart and rind [13].

5. Color determination: Heart color (CIE $L^{*}, a^{*}, b^{*}$ units) was measured on the cut surface of heart tissue using a Konica Minolta (model CM-3500d, Japan) calibrated with a white tile. $L^{*}$ degree of lightness $(100=$ white, $0=$ black), $a^{*}$ degree of redness or greenness (+red; -green), and $b^{*}$ degree of yellowness or blueness (+yellow; -blue). One reading was taken from each of six slices of each replicate sample [14] [15].

6. Total soluble solids content from juice extracts (tissue purees) were analyzed using an ABBE refractmeter, according to [12].

7. Fruits Weight was done by using electric scale (Jenaway), weighs up to $30 \mathrm{~kg}$ with accuracy of $0.01 \mathrm{~kg}$.

8. Dimensions were measured by using regular measuring tape $(100 \mathrm{~cm})$.

9. Rind thickness was measured by using vernier thickness caliper.

10. Soil analysis data: The soil in the planting sites was analyzed and the results are shown in Table 2.

\section{Results and Discussion}

With regard to Audrey cultivar, cow manure fertilizer was superior to other treatments regarding the number of fruits on each vine, number of vines and length of vine. The difference was statistically significant between cow manure, sheep manure and poultry manure and between chemical fertilizer and control sample $(P<0.05)$ as shown in Table 3. Dauda et al., 2008 studied the efficacy of different levels of poultry manure at the rates of 0 , 3.3, 6.6 and 9.9 tha $^{-1}$ on growth and yield of Citrullus lanatus, in Nigeria. They found that application of poultry manure significantly enhance growth parameter vigor and number of fruits during the two seasons [16].

When looking at Shapah cultivar, cow manure was the best in producing more fruits on each vine and other treatments: sheep manure, poultry manure, pigeons manure and chemical fertilizer. There was a significant difference among these treatments and control group but the difference was highly significant $(P<0.05)$ between cow manure and control group. These results are demonstrated in Table 4.

Table 2. Soil analysis data for planting sites.

\begin{tabular}{|c|c|c|c|c|c|c|c|}
\hline $\begin{array}{c}\text { Soil analysis } \\
\text { data }\end{array}$ & & & & & & & \\
\hline PPM & $\mathrm{g} / 100 \mathrm{~g}$ of soil & Millimose & $\mathrm{pH}$ & & & & \\
\hline Calcium & $\mathrm{K}$ & $\mathrm{P}$ & Mineral N & $\begin{array}{l}\text { Calcium } \\
\text { carbonate }\end{array}$ & Organic matter & EC $1 / 5$ & \\
\hline $18 \%$ & 213.4 & 11 & 9.42 & 42.66 & 1.4 & 0.29 & 5.9 \\
\hline
\end{tabular}


Table 3. Number of fruits, vines and length of vine in Audrey cultivar.

\begin{tabular}{cccccccc}
\hline Treatment & $\begin{array}{c}\text { No. of fruits } \\
\text { on each vine }\end{array}$ & $P$ value & $\begin{array}{c}\text { No. of } \\
\text { branches }\end{array}$ & $P$ value & Length of vine (cm) & $P$ value \\
\hline 1 & $4 \pm 0.26$ & $0.03^{*}$ & $15 \pm 4$ & $0.03^{*}$ & $98 \pm 20.4$ & $0.02^{*}$ \\
2 & $3 \pm 0.12$ & $0.04^{*}$ & $5 \pm 1$ & 0.10 & $66 \pm 19.9$ & $0.04^{*}$ \\
3 & $3 \pm 0.12$ & $0.04^{*}$ & $8 \pm 2$ & 0.07 & $82 \pm 20.69$ & $0.03^{*}$ \\
4 & $2 \pm 0.09$ & 0.06 & $8 \pm 2$ & 0.07 & $68 \pm 20.4$ & $0.04^{*}$ \\
5 & $2 \pm 0.09$ & 0.06 & $6 \pm 1$ & 0.2 & $42 \pm 10.76$ & 0.07 \\
6 & $1 \pm 0.03$ & & $6 \pm 1$ & & $33 \pm 9.94$ & & \\
\hline
\end{tabular}

*Significant difference $P<0.05$.

Table 4. Number of fruits, vines and length of vine in Shapah cultivar.

\begin{tabular}{ccccccc}
\hline Treatment & $\begin{array}{c}\text { No. of fruits on } \\
\text { each vine }\end{array}$ & $P$ value & No. of branches & $P$ value & Length of vine (cm) & $P$ value \\
\hline 1 & $3 \pm 0.12$ & $0.02^{*}$ & $17 \pm 4$ & $0.007^{*}$ & $70 \pm 19.84$ & $0.02^{*}$ \\
2 & $2 \pm 0.09$ & $0.04^{*}$ & $8 \pm 2$ & 0.06 & $97 \pm 25.33$ & $0.002^{*}$ \\
3 & $2 \pm 0.09$ & $0.04^{*}$ & $10 \pm 2$ & $0.04^{*}$ & $100 \pm 25.11$ & $0.001^{*}$ \\
4 & $2 \pm 0.09$ & $0.04^{*}$ & $12 \pm 3$ & $0.02^{*}$ & $88 \pm 22.85$ & $0.02^{*}$ \\
5 & $2 \pm 0.09$ & $0.04^{*}$ & $10 \pm 2$ & 0.04 & $96 \pm 24.85$ & $0.002^{*}$ \\
6 & $1 \pm 0.02$ & & $8 \pm 2$ & & $44 \pm 11.23$ & \\
\hline
\end{tabular}

* Significant difference $P<0.05$.

Data collected from this study have shown that in Audrey cultivar, cow manure had the highest length circumference comparing with control group $(P=0.02)$ followed by chemical fertilizer $(P=0.03)$. Sheep and pigeon manure were similar in their effect on length circumference $(85 \pm 20.8$ and $87 \pm 19.3)$ and the difference was significant $(P=0.04)$ but the difference was not significant between poultry manure and control group $(P=$ 0.05) as shown in Table 5. With regard to width circumference in Audrey cultivar, control group and chemical fertilizer had the highest width circumference but there was no significant difference between chemical fertilizer and control group regarding width circumference $(P=0.05)$ but the difference was significant between control group and all other treatments. Sheep and poultry manure ( $85 \pm 14.8$ and $80 \pm 13.9 \mathrm{~cm}$ respectively) and the difference was significant $(P=0.02)$ followed by pigeon manure and cow manure which were similar in their width circumference $(78 \pm 14.1$ and $75 \pm 13.3 \mathrm{~cm})$ and the difference was highly significant $(P=0.01)$.

Rind thickness was the highest in sheep and cow manure $(2.16 \pm 0.3 \mathrm{~cm}$ and $1.92 \pm 0.2 \mathrm{~cm}$ respectively) and the difference was significant compared with control group $(P=0.02)$, followed by poultry manure $1.78 \pm 0.2$ $\mathrm{cm}$ and pigeon manure $1.74 \pm 0.2 \mathrm{~cm}(P=0.04)$. There was no significant difference between control group and chemical fertilizer $(P=0.05)$. The weight of fruit was the highest in chemical fertilizer $18.37 \pm 4.9 \mathrm{~kg}(P=0.01)$ followed by cow manure $16.29 \pm 4.3 \mathrm{~kg}(P=0.02)$, sheep manure $15.5 \pm 4.2 \mathrm{~kg}(P=0.03)$, poultry and pigeon manure $14.26 \pm 3.9 \mathrm{~kg}$ and $13.26 \pm 3.6 \mathrm{~kg}(P=0.04)$. The lowest fruit weight was in the control group $10.62 \pm$ $2.1 \mathrm{~kg}$. This also applies to estimated yield (kg/Donum). The highest yield was in the chemical fertilizer 11026.2 $\pm 343.3 \mathrm{~kg} /$ Donum and the difference was highly significant $(P=0.007)$ when compared with the control group which had the lowest yield $(6370.2 \pm 132.1 \mathrm{~kg} /$ Donum). Cow manure came in the second place with $9970.4 \pm$ $250.4 \mathrm{~kg} /$ Donum $(P=0.01)$ followed by sheep manure $9300 \pm 233.3 \mathrm{~kg} /$ Donum $(P=0.02)$, poultry and pigeon manure (8558.6 \pm 243.5 and $7956.6 \pm 222.4 \mathrm{~kg} /$ Donum respectively $(P=0.04)$. Control group had the lowest yield (6370.2 $\pm 132.1 \mathrm{~kg} /$ Donum). These data are shown in Table 5 .

The results are in total agreement with those obtained by Olson and Simonne, 2010 who found that chemical fertilizers (NPK) had positive impact on watermelon productivity. In their study, chemical fertilizer gave around 90 tons/ ha which are very close to our result [17].

With regard to length circumference in Shapah cultivar, there was no significant difference between control group and treatment 6 but there was a significant difference between control group and other treatment $(P<$ 0.05). Treatments 2 and 3 came in the first and second place whereas treatment 1 and 4 were equal with regard 
Table 5. Fruit dimensions, rind thickness, fruit weight and estimated yield of Audrey cultivar.

\begin{tabular}{ccccccccccc}
\hline Treat. & $\begin{array}{c}\text { Length } \\
\text { circumference } \\
(\mathrm{cm})\end{array}$ & $P$ value & $\begin{array}{c}\text { Width } \\
\text { circumference } \\
(\mathrm{cm})\end{array}$ & $P$ value & $\begin{array}{c}\text { Rind } \\
\text { thickness } \\
(\mathrm{cm})\end{array}$ & $P$ value & $\begin{array}{c}\text { Weight } \\
\mathrm{kg}\end{array}$ & $P$ value & $\begin{array}{c}\text { Estimated yield } \\
(\mathrm{kg} / \text { Donum })\end{array}$ & $P$ value \\
\hline 1 & $97 \pm 23.3$ & $0.02^{*}$ & $75 \pm 13.3$ & $0.01^{*}$ & $1.92 \pm 0.2$ & $0.02^{*}$ & $16.29 \pm 4.3$ & $0.02^{*}$ & $9970.4 \pm 250.4$ & $0.01^{*}$ \\
2 & $85 \pm 20.8$ & $0.04^{*}$ & $85 \pm 14.8$ & $0.02^{*}$ & $2.16 \pm 0.3$ & $0.02^{*}$ & $15.5 \pm 4.2$ & $0.03^{*}$ & $9300 \pm 233.3$ & $0.02^{*}$ \\
3 & $81 \pm 18.9$ & 0.05 & $80 \pm 13.9$ & $0.02^{*}$ & $1.78 \pm 0.2$ & $0.04^{*}$ & $14.26 \pm 3.9$ & $0.04^{*}$ & $8558.6 \pm 243.5$ & $0.04^{*}$ \\
4 & $87 \pm 19.3$ & $0.04^{*}$ & $78 \pm 14.1$ & $0.01^{*}$ & $1.74 \pm 0.2$ & $0.04^{*}$ & $13.26 \pm 3.5$ & $0.04^{*}$ & $7956.6 \pm 222.4$ & $0.04^{*}$ \\
5 & $93 \pm 22.8$ & $0.03^{*}$ & $91 \pm 15.3$ & 0.05 & $1.62 \pm 0.1$ & 0.05 & $18.37 \pm 4.9$ & $0.01^{*}$ & $11026.2 \pm 343.3$ & $0.007^{*}$ \\
6 & $77 \pm 17.4$ & & $94 \pm 15.9$ & & $1.58 \pm 0.1$ & & $10.62 \pm 2.1$ & & $6370.2 \pm 132.1$ & \\
\hline
\end{tabular}

Significant difference $P<0.05$.

to this trait. The difference was significant between control group and all treatments with regard to width circumference. Treatments 4 and 5 were equal $(P=0.03)$ whereas treatments 1,2 and 3 were equal $(P=0.04)$.

Rind thickness was the highest in sheep manure $(1.5 \pm 0.3 \mathrm{~cm})$ and the difference was significant $(P=0.02)$, followed by pigeon manure and chemical fertilizer $1.38 \pm 0.2 \mathrm{~cm}(P=0.03)$. There was no significant difference between control group and cow manure $(P=0.05)$. The weight of fruit was the highest in poultry manure $11.9 \pm$ $2.43 \mathrm{~kg}(P=0.02)$ followed by sheep manure $11.39 \pm 2.53 \mathrm{~kg}(P=0.02)$, pigeon manure $10.6 \pm 2.12 \mathrm{~kg}(P=$ $0.03)$, cow manure $10.51 \pm 2.11 \mathrm{~kg}(P=0.03)$. The lowest fruit weight was in chemical fertilizer and control group and $9.79 \pm 1.78 \mathrm{~kg}$ and $9.47 \pm 1.33 \mathrm{~kg}(P=0.06)$. The highest yield $(\mathrm{kg} /$ Donum $)$ was in poultry manure $7140 \pm 1642.4 \mathrm{~kg} /$ Donum and the difference was significant $(P=0.02)$ when compared with the control group which had the lowest yield (5685.2 $\pm 1273.2 \mathrm{~kg} /$ Donum). Sheep manure came in the second place with $6836.4 \pm$ $1543 \mathrm{~kg} /$ Donum $(P=0.03)$ followed by pigeon manure $6360 \pm 1584.3 \mathrm{~kg} /$ Donum and cow manure $6309.6 \pm$ $1521(P=0.04)$, Control group had the lowest yield $(5685.2 \pm 1273.2 \mathrm{~kg} /$ Donum).There was no significant difference between control group and chemical fertilizer $(P=0.05)$. The data are presented in Table 6 . The results are similar to those obtained by Olson et al., 2010.

Poultry manure is relatively resistant to microbial degradation. However, it is essential for establishing and maintaining optimum soil physical condition and important for plant growth. PM is also very cheap and effective as a good source of $\mathrm{N}$ for sustainable crop production, but its availability remains an important issue due to its bulky nature, while inorganic fertilizer is no longer within the reach of poor-resource farmers due to its high cost. However, John et al. (2004) had advocated for an integral use of organic manure and inorganic Fertilizers for the supply of adequate quantities of plant nutrients required sustaining maximum crop productivity and profitability, while minimizing environmental impact from nutrient use [11].

With regard to seed percentage, chemical fertilizer and poultry manure had the highest percentage of seed (1.16\% and $1.12 \%$ respectively) followed by control group (0.98\%), sheep manure $(0.72 \%)$, pigeon manure $(0.63 \%)$ and finally cow manure that produced $0.57 \%$ seeds. As for moisture percentage in Audrey cultivar, control group had the highest moisture percentage (93\%), followed by chemical fertilizer $(91.1 \%)$ and then sheep, pigeon and poultry manure (90.96\%, 90.95\% and 90.13\% respectively). Cow manure gave the lowest moisture percentage $89.75 \%$.

Chemical fertilizers had the highest ash percentage $(0.44 \%)$ followed by poultry manure $(0.37 \%)$, control group and pigeon manure( $0.33 \%$ and $0.3 \%$ respectively) and finally cow manure and sheep manure $(0.23 \%$ and $0.22 \%$ respectively). $\mathrm{pH}$ values for Audrey cultivar for all treatment were very close, but pigeon manure had the highest $(\mathrm{pH}=5.8)$ followed by sheep manure, poultry manure and chemical fertilizer $(\mathrm{pH}=5.7)$ then control group and cow's fertilizer $(\mathrm{pH}=5.5)$ were the lowest.

When it comes to Total Soluble Solids (TSS), pigeon manure and chemical fertilizer had the highest (10.4 and 10.35 respectively) followed by cow manure (10.24), poultry manure (8.02), sheep manure (7.85) and finally control group (7.25). The results are presented in Table 7.

Shapah cultivar had different values for seeds, moisture and ash percentage, also had different values for $\mathrm{pH}$ and TSS for all treatments. Poultry manure had the highest seed percentage (1.68\%), followed by pigeon manure $(1.4 \%)$ then cow manure and control group (1.08\% and $1.06 \%$ respectively) and then chemical fertilizer $(0.99 \%)$ and finally sheep manure (0.87\%). Moisture percentage was the highest in sheep manure and chemical fertilizer (92.4\% and $92.16 \%$ respectively) followed by poultry manure $(91.43 \%)$, pigeon manure and control group 
Table 6. Fruit dimensions, rind thickness, fruit weight and estimated yield of Shapah cultivar.

\begin{tabular}{|c|c|c|c|c|c|c|c|c|c|c|}
\hline Treat. & $\begin{array}{l}\text { Length } \\
\text { circumference } \\
\text { (cm) }\end{array}$ & $P$ value & $\begin{array}{l}\text { Width } \\
\text { circumference } \\
\text { (cm) }\end{array}$ & $P$ value & $\begin{array}{l}\text { Rind } \\
\text { thickness } \\
\text { (cm) }\end{array}$ & $P$ value & $\begin{array}{l}\text { Weight } \\
\text { kg }\end{array}$ & $P$ value & $\begin{array}{l}\text { Estimated yield } \\
\text { (kg/Donum) }\end{array}$ & $P$ value \\
\hline 1 & $105 \pm 23.8$ & $0.04^{*}$ & $64 \pm 15.3$ & $0.03^{*}$ & $1.29 \pm 0.2$ & 0.05 & $10.51 \pm 2.11$ & $0.03^{*}$ & $6309.6 \pm 1521$ & $0.04^{*}$ \\
\hline 2 & $112 \pm 24.2$ & $0.02^{*}$ & $65 \pm 15.7$ & $0.03^{*}$ & $1.5 \pm 0.3$ & $0.02^{*}$ & $11.39 \pm 2.53$ & $0.02^{*}$ & $6836.4 \pm 1543$ & $0.03^{*}$ \\
\hline 3 & $111 \pm 21.6$ & $0.03^{*}$ & $64 \pm 14.5$ & $0.03^{*}$ & $1.26 \pm 0.2$ & $0.04^{*}$ & $11.9 \pm 2.43$ & $0.02^{*}$ & $7140 \pm 1642.4$ & $0.02^{*}$ \\
\hline 4 & $109 \pm 23.9$ & $0.04^{*}$ & $70 \pm 15.9$ & $0.02^{*}$ & $1.38 \pm 0.2$ & $0.03^{*}$ & $10.6 \pm 2.12$ & $0.03^{*}$ & $6360 \pm 1584.3$ & $0.04^{*}$ \\
\hline 5 & $99 \pm 20.8$ & 0.05 & $66 \pm 13.5$ & $0.02^{*}$ & $1.38 \pm 0.2$ & $0.03^{*}$ & $9.79 \pm 1.78$ & 0.06 & $5874.4 \pm 1320.3$ & 0.05 \\
\hline 6 & $103 \pm 23.4$ & & $64 \pm 13.8$ & & $1.18 \pm 0.1$ & & $9.47 \pm 1.33$ & & $5685.2 \pm 1273.2$ & \\
\hline
\end{tabular}

Significant difference $P<0.05$.

Table 7. Seeds, moisture, ash percentage, $\mathrm{pH}$ and TSS of Audrey cultivar.

\begin{tabular}{|c|c|c|c|c|c|}
\hline Treatment & Seed \% & Moisture \% & Ash \% & $\mathrm{pH}$ & TSS \\
\hline 1 & $0.57^{\mathrm{d}}$ & $89.75^{c}$ & $0.23^{\mathrm{c}}$ & $5.5^{b}$ & $10.24^{\mathrm{ab}}$ \\
\hline 2 & $0.72^{\mathrm{c}}$ & $90.96^{b}$ & $0.22^{\mathrm{c}}$ & $5.7^{\mathrm{ab}}$ & $7.85^{\mathrm{c}}$ \\
\hline 3 & $1.12^{\mathrm{a}}$ & $90.13^{b}$ & $0.37^{\mathrm{ab}}$ & $5.7^{\mathrm{ab}}$ & $8.02^{\mathrm{b}}$ \\
\hline 4 & $0.63^{\mathrm{cd}}$ & $90.95^{b}$ & $0.3^{\mathrm{b}}$ & $5.8^{\mathrm{a}}$ & $10.4^{\mathrm{a}}$ \\
\hline 5 & $1.16^{\mathrm{a}}$ & $91.1^{\mathrm{ab}}$ & $0.44^{\mathrm{a}}$ & $5.7^{\mathrm{ab}}$ & $10.35^{\mathrm{a}}$ \\
\hline 6 & $0.98^{\mathrm{b}}$ & $93^{\mathrm{a}}$ & $0.33^{b}$ & $5.5^{\mathrm{b}}$ & $7.25^{d}$ \\
\hline
\end{tabular}

Different letters denote significant difference.

(90.99\% and $90.58 \%$ respectively) whereas cow manure had the lowest moisture percentage for a value of $89.39 \%$. In the contrary, the highest ash percentage was in cow manure $(0.45 \%)$ followed by control group and chemical fertilizer $(0.41 \%)$ whereas sheep manure, poultry manure and pigeon manure had almost the same ash percentage $(0.36 \%)$.

Poultry manure and chemical fertilizer had the highest $\mathrm{pH}$ values $(\mathrm{pH}=5.6)$ followed by sheep $(5.5)$ and then cow's manure, control group and pigeon manure $(\mathrm{pH}=5.3$ - 5.4). Pigeon manure had the highest TSS (10.6) followed by chemical fertilizer (10.4), cow manure (10.1) followed by sheep manure and control group (8.1 and 7.9 respectively). Poultry manure had the lowest TSS in Shapah cultivar for 7.1 as shown in Table 8 . The results obtained from this study especially $\mathrm{pH}$ values and poultry manure was similar to those obtained by Duda et al., 2005 in which he found that chemical fertilizer increased $\mathrm{pH}$ values of soils.

The superficial appearance and color of food are the first parameters of quality evaluated by consumers, and are thus critical factors for acceptance of the food item by the consumer [18].

The aspect and color of the food surface is the first quality parameter evaluated by consumers and is critical in the acceptance of the product, even before it enters the mouth. The color of this surface is the first sensation that the consumer perceives and uses as a tool to accept or reject food [19].

This study has also examined the degree of lightness (L), the degree of redness or greenness (a) and the degree of yellowness or blueness (b) in both cultivars.

In Audrey cultivar, chemical fertilizer had the highest lightness degree $(\mathrm{L}=41.44)$ followed by poultry manure and control group (32.08 and 32.07 respectively) whereas sheep manure and pigeon manure had 30.19 and 30.18 respectively. Pigeons manure had the highest score with regard to redness (30.95) followed by chemical fertilizer and poultry manure (29.23 and 29.13 respectively) and then control group (28.84), cow manure (28.5) and finally sheep manure for a value of 28.15. Yellowness score was the highest pigeon manure and chemical fertilizer (16.76 and 16.26 respectively) followed by poultry manure (15.58), control group and cow manure (14.44 and 14.23 respectively) whereas the sheep manure was the lowest (13.43). These results are shown in Table 9 and are similar to the results found by Pedreschi et al., 2000 [20].

Table 9 has shown that the highest lightness score in Shapah cultivar was in cow manure (32.78) followed by pigeon manure, chemical fertilizer and control group (30.81 and 30.36 respectively). Poultry manure and sheep manure had the lowest lightness score 29.98 and 29.47. 
Table 8. Seeds, moisture, ash percentage, pH and TSS of Shapah cultivar.

\begin{tabular}{|c|c|c|c|c|c|}
\hline Treatment & Seed \% & Moisture \% & Ash \% & $\mathrm{pH}$ & TSS \\
\hline 1 & $1.08^{\mathrm{b}}$ & $89.39^{c}$ & $0.45^{\mathrm{a}}$ & $5.4^{\mathrm{b}}$ & $10.1^{\mathrm{b}}$ \\
\hline 2 & $0.87^{\mathrm{d}}$ & $92.4^{\mathrm{a}}$ & $0.36^{\mathrm{b}}$ & $5.5^{\mathrm{ab}}$ & $8.1^{\mathrm{bc}}$ \\
\hline 3 & $1.68^{\mathrm{a}}$ & $91.43^{\mathrm{ab}}$ & $0.35^{\mathrm{b}}$ & $5.6^{\mathrm{a}}$ & $7.1^{\mathrm{c}}$ \\
\hline 4 & $1.4^{\mathrm{ab}}$ & $90.99^{b}$ & $0.36^{b}$ & $5.3^{b}$ & $10.6^{\mathrm{a}}$ \\
\hline 5 & $0.99^{c}$ & $92.16^{a}$ & $0.41^{\mathrm{ab}}$ & $5.6^{\mathrm{a}}$ & $10.4^{\mathrm{ab}}$ \\
\hline 6 & $1.06^{\mathrm{b}}$ & $90.58^{b}$ & $0.41^{\mathrm{ab}}$ & $5.4^{\mathrm{b}}$ & $7.9^{\mathrm{bc}}$ \\
\hline
\end{tabular}

Different letters denote significant difference in the column.

Table 9. Heart color measurement (units) of both Audrey and Shapah cultivars.

\begin{tabular}{|c|c|c|c|c|c|c|}
\hline Treatment & Audrey cultivar & Shapah cultivar & & & & \\
\hline & $\mathrm{L}^{*}$ & $a^{*}$ & $\mathrm{~b}^{*}$ & $\mathrm{~L}^{*}$ & $a^{*}$ & $\mathrm{~b}^{*}$ \\
\hline 1 & $31.63^{b}$ & $28.5^{b}$ & $14.25^{\mathrm{bc}}$ & $32.78^{a}$ & $30.29^{b}$ & $17.04^{\mathrm{a}}$ \\
\hline 2 & $30.19^{b c}$ & $28.15^{b}$ & $13.43^{c}$ & $29.47^{b}$ & $31.94^{\mathrm{ab}}$ & $16.39^{\mathrm{b}}$ \\
\hline 3 & $32.08^{\mathrm{ab}}$ & $29.15^{\mathrm{ab}}$ & $15.58^{b}$ & $29.98^{b}$ & $32.53^{\mathrm{a}}$ & $16.48^{b}$ \\
\hline 4 & $30.18^{b c}$ & $30.95^{\mathrm{a}}$ & $16.76^{\mathrm{a}}$ & $30.81^{\mathrm{ab}}$ & $31.14^{\mathrm{ab}}$ & $16.75^{\mathrm{ab}}$ \\
\hline 5 & $41.44^{\mathrm{a}}$ & $29.23^{\mathrm{ab}}$ & $16.26^{a}$ & $30.36^{\mathrm{ab}}$ & $30.62^{b}$ & $16.02^{b c}$ \\
\hline 6 & $32.07^{\mathrm{ab}}$ & $28.84^{b}$ & $14.44^{b c}$ & $30.36^{\mathrm{ab}}$ & $30.63^{b}$ & $15.45^{\mathrm{c}}$ \\
\hline
\end{tabular}

Different letters denote significant difference in the column.

Redness score in Shapah cultivar was the highest in poultry manure (32.53) maybe was due to increase lycopene content of the flesh [21] followed by sheep manure and pigeon manure (31.94 and 31.14) whereas control group, chemical fertilizer and cow manure scored the lowest in redness scores (30.63, 30.62 and 30.29 respectively). Yellowness score was the highest in cow manure (17.04) followed by pigeons manure (16.75). Poultry manure and sheep manure had almost the same value (16.48 and 16.39 respectively) and then chemical fertilizer (16.02) whereas the lowest was control group (15.45).

The results obtained from this study are parallel to those results reported by Vimala et al., 2001 who found that the chemical fertilizer has a great effect on the color of the flesh and heart of watermelon, which was due by increasing lycopene content of the flesh [22].

\section{Conclusion}

As a conclusion for this study, organic fertilizers mainly cows, sheep and poultry manure had the highest results with regard to quality parameters such as redness and rind thickness whereas chemical fertilizer had a slight advantage for the productivity (kg/Donum) compared with control and organic fertilizer, but quality parameters were lower than organic fertilizers especially in those cows, sheep and poultry manure.

\section{References}

[1] Koocheki, A., Razavi, S.M.A., Milani, E., Moghadan, T.M., Abedini, M., Alamatiyan, S. and Izadikhah, S. (2007) Physical Properties of Watermelon Seed as a Function of Moisture Content and Variety. International Agrophysics, 21, 349-359.

[2] Perkins-Veazie, P. and Collins, J.K. (2004) Flesh Quality and Lycopene Stability of Fresh-Cut Watermelon. Postharvest Biology and Technology, 31, 159-166.

[3] Perkins-Veazie, P., Collins, J.K, Pair, S.D. and Roberts, W. (2001) Lycopene Content Differs among Red-Fleshed Watermelon Cultivars. Journal of the Science of Food and Agriculture, 81, 983-987. http://dx.doi.org/10.1002/jsfa.880

[4] Erukainure, O.L., Oke, O.V., Daramola, A.O., Adenekan, S.O. and Umanhonlen, E.E. (2010) Improvement of the Biochemical Properties of Watermelon Rinds Subjected to Saccharomyces cerevisae Solid Media Fermentation. Paskistan Journal of Nutrition, 9, 806-809. http://dx.doi.org/10.3923/pjn.2010.806.809

[5] FAO (2007) FAOSTAT Data 2007. FAO Statistical Database. Agriculture, 6 December 2007. 
[6] FAO Statistics (2011) Food and Agriculture Organization of the United Nations, Production Yearbook 2003. Vol. 57, Rome.

[7] Pamplona-roger, G.D. (2008) Healthy Foods. First Edition, San Fernando de Henares, Madrid.

[8] Dauda, S.N., Aliya, L., and Chiezey, U.F. (2005) Effect of Variety, Seedling Age and Poultry Manure on Growth and Yield of Garden Egg (Solamun gilo L.). Nigerian Academic Forum, 9, 88-95.

[9] Mahmoud, E., Abd EL-Kader, N., Robin, P., Akkal-Corfini, N. and Abd El-Rahman, L. (2009) Effects of Different Organic and Inorganic Fertilizers on Cucumber Yield and Some Soil Properties. World Journal of Agriculture Sciences 5, 408-414.

[10] Wakui, Y. (2009) Organic Farming Technology in Japan. Pilot Project for Better Farm Income by Organic-Based Vegetable Production. Koibuchi College of Agriculture and Nutrition, MITO.

[11] John, L.W., Jamer, D.B., Samuel, L.T. and Warner, L.W. (2004) Soil Fertility and Fertilizers: An Introduction to Nutrient Management. Person Education, Delhi, 106-153.

[12] AOAC. (2002) Official Methods of Analysis of AOAC, INTERNSTIONAL 17th Addition, Current.

[13] Xisto, A.L.R.P., Vilas Boas, E.V.B., Nunes, E.E., Vilas Boas, E.M. and Mário César Guerreiro, M.C. (2012) Volatile Profile and Physical, Chemical, and Biochemical Changes in Fresh-Cut Watermelon during Storage. Food Science and Technology (Campinas), 32, 173-178.

[14] Saftner, R., Luo, Y., McEvoy, J., Abbott, J.A. and Vinyard, B. (2007) Quality Characteristics of Fresh-Cut Watermelon Slices from Non-Treated and 1-methylcyclopropene and/or Ethylene-Treated Whole Fruit. Postharvest Biology and Technology, 44, 71-79. http://dx.doi.org/10.1016/j.postharvbio.2006.11.002

[15] Nadzirah, K.Z., Zainal, S., Noriham, A., Normah, I., Siti Roha, A.M. and Nadya, H. (2013) Physico-Chemical Properties of Pineapple Variety N36 Harvested and Stored at Different Maturity Stages. International Food Research Journal, 20, 225-231.

[16] Dauda, S.N., Ajayi, F.A. and Ndor, E. (2008) Growth and Yield of Watermelon (Citrullus lanatus) as Affected by Poultry Manure Application. Journal of Agriculture \& Social Sciences, 4, 121-124.

[17] Olson, S.M. and Simonne, E. (2010) The Vegetable Production Handbook for Florida. Vance Publishers, Lenexa, 291-312.

[18] Leon, K., Mery, D., Pedreschi, F. and Leon, J. (2006) Color Measurement in L*a*b* Units from RGB Digital Images. Food Research International, 39, 1084-1091. http://dx.doi.org/10.1016/j.foodres.2006.03.006

[19] Du, C. and Sun, D. (2004) Recent Developments in the Applications of Image Processing Techniques for Food Quality Evaluation. Trends in Food Science and Technology, 15, 230-249. http://dx.doi.org/10.1016/j.tifs.2003.10.006

[20] Pedreschi, F., Aguilera, J.M. and Brown, C.A. (2000) Characterization of Food Surfaces Using Scale-Sensitive Fractal Analysis. Journal of Food Process Engineering, 23, 127-143. http://dx.doi.org/10.1111/j.1745-4530.2000.tb00507.x

[21] Abdullah, M.Z., Guan, L.C., Lim, K.C. and Karim, A.A. (2004) The Applications of Computer Vision and Tomographic Radar Imaging for Assessing Physical Properties of Food. Journal of Food Engineering, 61, 125-135. http://dx.doi.org/10.1016/S0260-8774(03)00194-8

[22] Vimala, P., Salbiah, H., Zaharah, T. and Ruwaida, M. (2001) Yield Responses of Vegetables to Organic Feritilizers. Journal of Tropical Agriculture and Food Science, 29, 17-28. 